\title{
Front Matter: Volume 8132
}

, "Front Matter: Volume 8132," Proc. SPIE 8132, Time and Frequency Metrology III, 813201 (7 October 2011); doi: 10.1117/12.915544

SPIE Event: SPIE Optical Engineering + Applications, 2011, San Diego, California, SPIE. United States 


\section{PROCEEDINGS OF SPIE}

\section{Time and Frequency Metrology III}

Tetsuya Ido

Thomas R. Schibli

Editors

24-25 August 2011

San Diego, California, United States

Sponsored and Published by

SPIE

Volume 8132

Proceedings of SPIE, 0277-786X, v. 8132 
The papers included in this volume were part of the technical conference cited on the cover and title page. Papers were selected and subject to review by the editors and conference program committee. Some conference presentations may not be available for publication. The papers published in these proceedings reflect the work and thoughts of the authors and are published herein as submitted. The publisher is not responsible for the validity of the information or for any outcomes resulting from reliance thereon.

Please use the following format to cite material from this book:

Author(s), "Title of Paper," in Time and Frequency Metrology III, edited by Tetsuya Ido, Thomas R. Schibli, Proceedings of SPIE Vol. 8132 (SPIE, Bellingham, WA, 2011) Article CID Number.

ISSN 0277-786X

ISBN 9780819487421

Published by

SPIE

P.O. Box 10, Bellingham, Washington 98227-0010 USA

Telephone +1 3606763290 (Pacific Time) · Fax +1 3606471445

SPIE.org

Copyright () 2011, Society of Photo-Optical Instrumentation Engineers

Copying of material in this book for internal or personal use, or for the internal or personal use of specific clients, beyond the fair use provisions granted by the U.S. Copyright Law is authorized by SPIE subject to payment of copying fees. The Transactional Reporting Service base fee for this volume is $\$ 18.00$ per article (or portion thereof), which should be paid directly to the Copyright Clearance Center (CCC), 222 Rosewood Drive, Danvers, MA 01923. Payment may also be made electronically through CCC Online at copyright.com. Other copying for republication, resale, advertising or promotion, or any form of systematic or multiple reproduction of any material in this book is prohibited except with permission in writing from the publisher. The CCC fee code is 0277-786X/11/ \$18.00.

Printed in the United States of America.

Publication of record for individual papers is online in the SPIE Digital Library.

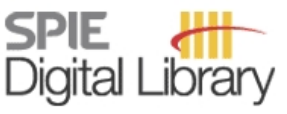

SPIEDigitalLibrary.org

Paper Numbering: Proceedings of SPIE follow an e-First publication model, with papers published first online and then in print and on CD-ROM. Papers are published as they are submitted and meet publication criteria. A unique, consistent, permanent citation identifier (CID) number is assigned to each article at the time of the first publication. Utilization of CIDs allows articles to be fully citable as soon as they are published online, and connects the same identifier to all online, print, and electronic versions of the publication. SPIE uses a six-digit CID article numbering system in which:

- The first four digits correspond to the SPIE volume number.

- The last two digits indicate publication order within the volume using a Base 36 numbering system employing both numerals and letters. These two-number sets start with 00, 01, 02, 03, 04 , $05,06,07,08,09,0 A, 0 B \ldots$. OZ, followed by 10-1Z, 20-2Z, etc.

The CID number appears on each page of the manuscript. The complete citation is used on the first page, and an abbreviated version on subsequent pages. Numbers in the index correspond to the last two digits of the six-digit CID number. 


\section{Contents}

$\checkmark$ Conference Committee

\section{SESSION 1}

813202 Precision spectroscopy on atomic hydrogen (Invited Paper) [8132-01]

C. G. Parthey, A. Matveev, J. Alnis, A. Beyer, R. Pohl, K. Predehl, T. Udem, N. Kolachevsky, Max-Planck-Institut für Quantenoptik (Germany); M. Abgrall, D. Rovera, LNE-SYRTE, Observatoire de Paris (France); C. Salomon, Lab. Kastler-Brossel, CNRS (France); P. Laurent, LNE-SYRTE, Observatoire de Paris (France); T. W. Hänsch, Max-Planck-Institut für Quantenoptik (Germany) and Ludwig-Maximilians-Univ. München (Germany)

813204 High harmonic generation in VUV via passive enhancement of near infrared femtosecond pulses [8132-03]

K. Wakui, K. Hayasaka, National Institute of Information and Communications Technology (Japan); T. Ido, National Institute of Information and Communications Technology (Japan) and Japan Science and Technology Agency (Japan)

813205 Numerical simulations of high intensity pulse trains and plasma dynamics in passive femtosecond enhancement cavities [8132-04]

D. R. Carlson, J. Mongelli, E. M. Wright, R. J. Jones, College of Optical Sciences, The Univ. of Arizona (United States)

\section{SESSION 2}

813207 Overcoming the quantum projection noise (QPN) limit without preparation of the spinsqueezed state [8132-07]

N. Shiga, Japan Science and Technology Agency (Japan) and National Institute of Information and Communications Technology (Japan); M. Takeuchi, The Univ. of Tokyo (Japan)

\section{SESSION 3}

813209 Frequency shifts of colliding fermions in optical lattice clocks (Invited Paper) [8132-10] K. Gibble, The Pennsylvania State Univ. (United States)

\section{SESSION 4}

$81320 \mathrm{~A}$ Optical direct comparison of ${ }^{87} \mathrm{Sr}$ optical lattice clocks using a $>50 \mathrm{~km}$ telecommunication fiber link [8132-11]

H. Hachisu, A. Yamaguchi, National Institute of Information and Communications Technology (Japan) and Japan Science and Technology Agency (Japan); M. Fujieda, M. Kumagai, S. Nagano, Y. Li, National Institute of Information and Communications Technology (Japan); T. Ido, National Institute of Information and Communications 
Technology (Japan) and Japan Science and Technology Agency (Japan); T. Takano, M. Takamoto, H. Katori, The Univ. of Tokyo (Japan) and Japan Science and Technology Agency (Japan)

8132 OB Frequency comparison of optical lattice clocks (Invited Paper) [8132-12]

M. Takamoto, T. Takano, The Univ. of Tokyo (Japan) and Japan Science and Technology Agency (Japan); H. Katori, The Univ. of Tokyo (Japan), Japan Science and Technology Agency (Japan), and RIKEN (Japan)

\section{SESSION 5}

8132 OD Atomic frequency standards at NICT (Invited Paper) [8132-14]

T. Ido, National Institute of Information and Communications Technology (Japan) and Japan Science and Technology Agency (Japan); M. Fujieda, National Institute of Information and Communications Technology (Japan); H. Hachisu, National Institute of Information and Communications Technology (Japan) and Japan Science and Technology Agency (Japan); K. Hayasaka, M. Kajita, R. Kojima, M. Kumagai, C. Locke, Y. Li, K. Matsubara, A. Nogami, National Institute of Information and Communications Technology (Japan); N. Shiga, Japan Science and Technology Agency (Japan) and National Institute of Information and Communications Technology (Japan); A. Yamaguchi, National Institute of Information and Communications Technology (Japan) and Japan Science and Technology Agency (Japan); Y. Koyama, M. Hosokawa, Y. Hanado, National Institute of Information and Communications Technology (Japan)

8132 OE Recent progress of time and frequency research in NIM (Invited Paper) [8132-15] Y. Lin, Beijing Institute of Technology (China) and National Institute of Metrology (China); Z. Fang, T. Li, National Institute of Metrology (China)

\section{SESSION 6}

8132 OF Current status of the ${ }^{171} \mathrm{Yb}$ optical lattice clock at NMIJ, AIST (Invited Paper) [8132-16] M. Yasuda, T. Kohno, K. Hosaka, H. Inaba, Y. Nakajima, D. Akamatsu, F.-L. Hong, National Institute of Advanced Industrial Science and Technology (Japan)

8132 0G Time and frequency activities at NRC (Invited Paper) [8132-17]

P. Dubé, A. A. Madej, J. E. Bernard, L. Marmet, M. Gertsvolf, National Research Council Canada (Canada)

$8132 \mathrm{OH}$ Time and frequency metrology at PTB: recent results (Invited Paper) [8132-18]

V. Gerginov, Physikalisch-Technische Bundesanstalt (Germany)

Author Index 


\title{
Conference Committee
}

\author{
Program Track Chair
}

Khan M. Iftekharuddin, The University of Memphis (United States)

Conference Chairs

Tetsuya Ido, National Institute of Information and Communications Technology (Japan)

Thomas R. Schibli, JILA (United States) and University of Colorado at Boulder (United States)

Program Committee

John G. Hartnett, The University of Western Australia (Australia)

Hajime Inaba, National Institute of Advanced Industrial Science and Technology (Japan)

R. Jason Jones, College of Optical Sciences, The University of Arizona (United States)

Ekkehard Peik, Physikalisch-Technische Bundesanstalt (Germany)

John D. Prestage, Jet Propulsion Laboratory (United States)

Jun Ye, JILA (United States)

\section{Session Chairs}

1 Nobuyasu Shiga, National Institute of Information and Communications Technology (Japan)

2 Tetsuya Ido, National Institute of Information and Communications Technology (Japan)

3 Matthew Swallows, JILA (United States)

$4 \quad$ Hajime Inaba, National Institute of Advanced Industrial Science and Technology (Japan)

5 Masami Yasuda, National Institute of Advanced Industrial Science and Technology (Japan)

6 R. Jason Jones, College of Optical Sciences, The University of Arizona (United States) 
Downloaded From: https://www.spiedigitallibrary.org/conference-proceedings-of-spie on 26 Apr 2023

Terms of Use: https://www.spiedigitallibrary.org/terms-of-use 